\title{
JUGGLERS AT THE TRAFFIC LIGHTS: A BIBLIOGRAPHICAL REVISION
}

\author{
Ana Carolina Assis SAMPAIO'; Carlos Alberto ISAZA²
}

\author{
${ }^{1}$ Graduanda em Administração/Universidade Federal da Paraíba (UFPB), Brasil. E-mail: \\ anacassissampaio@gmail.com \\ ${ }^{2}$ Graduação em Contaduría Pública/Universidad de Valle (UNIVALLE), Colombia. E-mail: \\ carlos0isaza@gmail.com
}

\begin{abstract}
Juggling as art, were always present in the history of the development of human civilization in the course of the centuries. This practice, actually has occupied the street spaces, thus various other arts. In this point, the circus arts and juggling specifically, had to reinvent and adapt to the new social realities, using the traffic lights as showcase and workplace. The street, understood as a place of insecurities and risks, emerge for the artists as a perfect stage to allow access to all individuals of the population independent of class, race or gender. In this way street art, especially juggling in the traffic light, has been gaining more and more space within cities. This study sought to get a better understand about the practice of juggling in the traffic light, approached from economic, cultural and social perspectives. This practice increasingly present in urban territory, present few scientific studies and limited knowledge and attention of the academic community. In pursuit of this understanding, was used content analysis, quantitative and qualitative perspective of the bibliographic collection selected. It was possible to observe the academy's perspective on this activity, which mostly opted for a socioeconomic approach. The researchers' perception of juggling at traffic lights as art also had significant expression of the collection studied, in which the activity is analyzed from an internal perception, as participating observers. Finally, the topic 'backpackers' with the lowest representativeness in the analyzed bibliographic material, in which is observed the existent relationship between this group and the studied activity.
\end{abstract}

Keywords: Juggling; Street Art; Backpackers.

\section{MALABARISTAS NO SEMÁFORO: UMA REVISÃO BIBLIOGRÁFICA}

Resumo. O malabar como arte, sempre esteve presente na história do desenvolvimento da civilização humana no decorrer dos séculos. Essa prática, na atualidade tem ocupado o espaço da rua, assim como diversas outras artes. Nesse sentido, as artes circenses e especificamente os malabares, tiveram que se reinventar e adaptar às novas realidades sociais, tendo o semáforo como vitrine e local de trabalho. A rua, entendida como um local de inseguranças e de riscos, se apresenta para os artistas como um palco perfeito para que todos os indivíduos da população, independente de classe, cor, gênero, tenham acesso. Desta forma, a arte de rua com um todo, e em especial os malabares no semáforo, vem 
ganhando cada vez mais espaço dentro das cidades. Este estudo buscou compreender melhor acerca da prática dos malabares quando realizados no semáforo, sendo abordado desde perspectivas econômica, cultural e social. Tal prática, cada vez mais presente no território urbano, apresenta poucos estudos científicos bem como pouco conhecimento e atenção da comunidade acadêmica. Na busca desta compreensão, utilizou-se análise de conteúdo, a perspectiva quantitativa e qualitativa, do acervo bibliográfico. Foi possível observar a perspectiva da academia acerca desta atividade que, em sua maioria, optou por um olhar socioeconômico. A percepção dos pesquisadores em relação aos malabares no semáforo como arte também teve expressão significativa do acervo estudado, em que se analisa a partir de uma percepção mais interna a atividade, como observadores participantes. Por fim, o tópico 'mochileiro' com a menor representatividade no material bibliográfico analisado, em que se observa a relação existente entre este grupo e a atividade estudada.

Palavras-chave: Malabarismo; Arte de Rua; Mochileiros.

\section{MALABARISTAS EN EL SEMÁFORO: UNA REVISIÓN BIBLIOGRÁFICA}

Resumen. El malabar como arte, siempre estuvo presente en la historia del desarrollo de la civilización humana en el transcurrir de los siglos. Esa práctica, en la actualidad ha ocupado el espacio de la calle, así como diversas otras artes. En ese sentido, las artes circenses y específicamente los malabares, tuvieron que reinventarse y adaptarse a las nuevas realidades sociales, teniendo el semáforo como vitrina y local de trabajo. La calle, entendida como un local de inseguridad y riesgos, se presenta para los artistas como un palco perfecto para que todos os individuos de la población, independientes de clase, color, género; tengan acceso. De esta forma el arte callejero, y en especial los malabares en el semáforo, vienen ganando cada vez más espacio dentro de las ciudades. Este estudio buscó comprender mejor acerca de la práctica de los malabares cuando realizados en el semáforo, siendo abordado desde perspectivas económicas, culturales y sociales. Tal práctica, cada vez más presente en el territorio urbano, presenta pocos estudios científicos, así como poco conocimiento y atención de la comunidad académica. En la búsqueda de esta comprensión, se utilizó análisis de contenido, la perspectiva cuantitativa y cualitativa del acervo bibliográfico. Fue posible observar la perspectiva de la academia acerca de esta actividad que, en su mayoría, optó por una mirada socioeconómica. La percepción de los investigadores en relación a los malabaristas en el semáforo como arte también tuvo expresión significativa del acervo estudiado, en el cual se analiza a partir de una percepción más interna la actividad, como observadores participantes. Por fin, el tópico 'mochilero' con una menor representatividad en el material bibliográfico analizado, en el que se observa la relación existente entre este grupo y la actividad estudiada.

Palabras clave: Malabarismo; Arte Callejero; Mochileros. 


\section{INTRODUCTION}

Juggling is a circus art that involves maneuvering objects in the air. This art as many others, conquered the urban space, taking streets as stage and population as audience. In this sense, the juggling practice at traffic lights is an activity increasingly present into the environment of big and medium cities of America Latina, existing among residents, pedestrians and motorists of these spaces. Meanwhile, there is little documentary content and scientific research about on this specific topic. In this sense, the present work search to explain the activity of juggling artists at traffic lights, making a critical analysis of what the academy says about it.

Therefore, the method of bibliographic review of the articles published between 2014 and 2018 was chosen, in order to analyze the most recent and adequate content for an actual analysis. For a still more concrete analysis, the theory of "content analysis" of Bardin (1977) was taken, using a categorical analysis in the quantitative perspective and analysis of the description of the message in the qualitative approach.

In the analysis of the bibliographic content, a total of 20 articles were reviewed, was observed that the central themes could be divided into three categories: socioeconomic, art and backpackers. The quantitative results showed that $45 \%$ of the collection was classified as socioeconomic, $40 \%$ in art and $15 \%$ in backpackers. The socioeconomic category present a vision of this activity relating it to poverty, social inequality, begging and child exploitation, this last aspect representing $50 \%$ of the collection of that subcategory.

The other categories analyze the activity of juggling at the traffic light from a more positive perspective, expressing their representation for street art as whole, as an expression of urban art and social groups. This activity taken by travelers, marginal population and peripheral children and youth community, is an art and been exhibited as an expression of urban culture. The present work is composed, in addition to the introductory part, by the methodology, presentation of the results and discussion, followed by conclusion and references; looking to achieve the intention for which it was created.

\section{MATERIAL AND METHODS}

For this work was used the method of bibliographic revision, in order to better understand the topic addressed, and to explore the academic and theoretical vision of the subject. As it is not an issue frequently addressed within the scientific academy, the use of more specific web pages like Spell, Scielo, among others, was not viable. Therefore, the Google Academic platform (https://scholar.google.com.br/) was used to include various other collections, such as Scielo, University of Brasilia, Pontificia Universidad Católica, Universidad del Córdoba, 
among others, thus being able to, expand the amount of material for analysis. It should also be noted that national and international bibliographic collections were used.

The bibliographic material was composed of articles published from 2014 to 2018. Such a temporary cut was elected to observe the content and the most recent approach to the topic. At the beginning the documentary research the expression used was "street art", meanwhile, the articles that address this topic did not present material about the jugglers at the traffic lights. With the amplitude of the activities involved in street art, only three articles discuss about or issue that the present work seeks to understand. Therefore, we chose to use the words "juggling" and "traffic light" for research, selecting articles studying the individuals present within the traffic light territory and the work in those spaces. In order to get a better focus on the subject, preferentially studied articles addressing the characters that perform the practice of juggling within the traffic light space. These because many materials that presented the words sought showed a very divergent approach to the perspective sought in this study, as for example, the article that studies the teaching of physics for elementary students.

Capturing 20 articles, from various fields of study (physical education, sociology, pedagogy, geography, psychology, social service, arts, and others); this article analyzes what is the academic / scientific understanding of juggling in the traffic light. Applying a quantitative and qualitative methodology, analysis of the content of the collected material was also used. The election of the method based in the need to be able to perform a better study of the bibliographic collection obtained.

The qualitative approach allow an analysis of the "description of message content" (BARDIN, 1977 p. 34) facilitating therefore to interpret the ideas addressed in the bibliography. In the quantitative aspect, also according to the techniques of content analysis presented by Bardin (1977), the "categorical analysis" was chosen, establishing therefore an objective classification of the articles. Three central themes classified from the analysis of the articles: social problems, street art and backpackers.

For the establishment of such division, the following steps were used: (a) reading of the collected material; (b) identification of the central idea; (c) classification of ideas; (d) analysis of the articles, seeking interaction and dialog between them; (e) construction of the critical synthesis in the results, highlighting the categories discussed and (f) elaboration of the discussion addressing the peculiar characteristics intrinsic to the activity as art and as work, exposing a new academic perspective on the subject. 
The stage of the results expose the quantitative analyzes realized, in which the percentage division of the subjects addressed in the established categories. The discussion presents the qualitative aspects of the analysis in which the content provided by the examined bibliographic collection.

\section{RESULTS}

The results presented objectively, the juggling at the traffic lights from the academic perspective. Mentioned by Araújo (2017), the history of the circus and the street circus, lesser studied from the scientific angle, presented a "marginal knowledge in relation to other artistic activities" (ARAÚJO, 2017, p. 29). Juggling at the streetlights, as result of an adapted and marginalized circus culture, present as well the characteristic of 'marginal knowledge' approached by the author.

The collected articles present studies about the characters that perform the practice of Malabar at the traffic light (Fig. 1), the socio-economic, artistic and itinerant workers perspectives allows the analysis of the scientific material. In this way, the analysis of the material yielded a classification constructed from the observation of the perspective presented by the authors in three categories: Socioeconomic, Art and Backpackers.

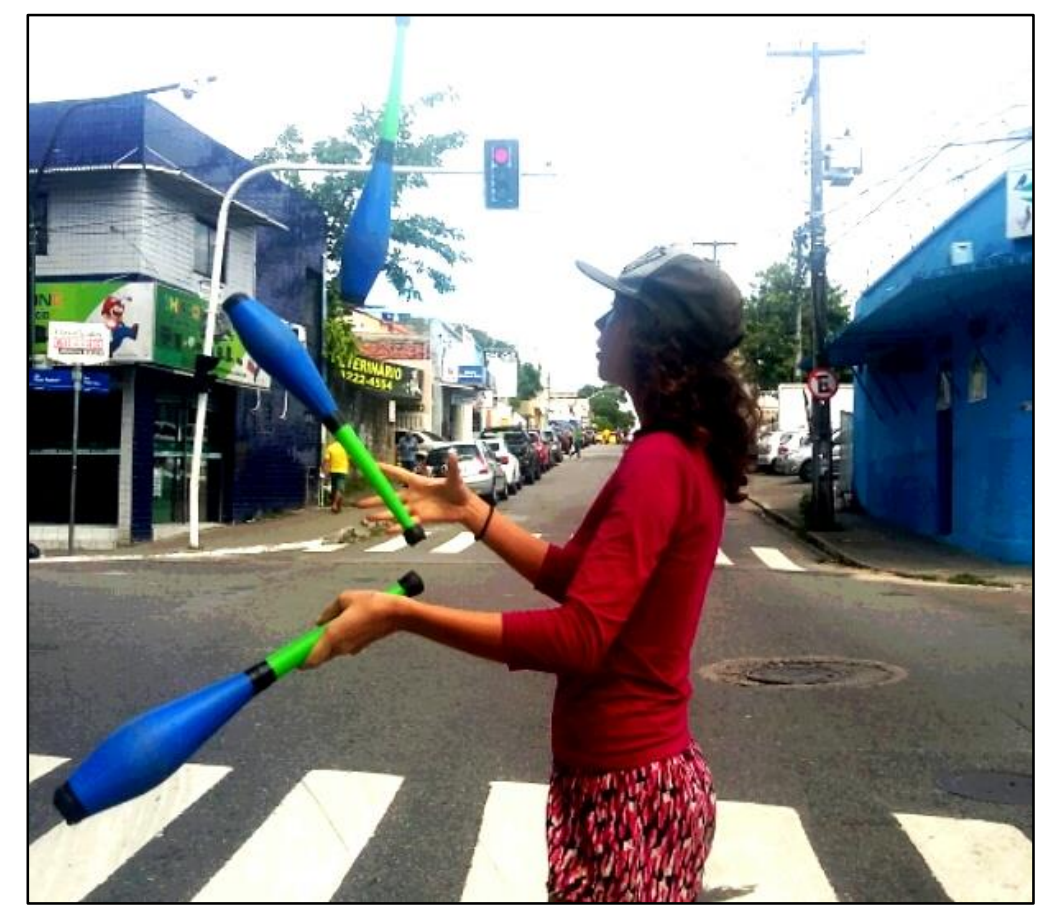

Figure 1. Street light juggler (Ana Sampaio) in the city of João Pessoa, state of Paraíba, Northeast Brazil. Photo: Carlos Isaza, 2018. 
Thus, the scientific articles collected were classified, being possible to observe, in the totality of the 20 articles, 9 are classified in the category 'socioeconomic', 8 in the category 'art' and 3 in the category 'backpackers' (Tab. 1).

Table 1. Proposal of classification of articles, based on revised bibliography.

\begin{tabular}{|c|c|c|c|}
\hline \multicolumn{2}{|r|}{ AUTHORS } & TITLE & YEAR \\
\hline \multicolumn{4}{|c|}{ SOCIOECONOMIC PROBLEMS } \\
\hline 1 & DE ATAÍDE & Meninos Públicos na Via Pública & 2016 \\
\hline 2 & BARBOSA & Territórios dos Excluídos & 2014 \\
\hline 3 & ECKER & Crianças em situação de rua & 2017 \\
\hline 4 & $\begin{array}{l}\text { BUSCARIOLLI; } \\
\text { CARNEIRO; SANTOS }\end{array}$ & Artistas de Rua & 2016 \\
\hline 5 & GÓMEZ; LÓPEZ; YEPES & $\begin{array}{l}\text { El trabajo infantil en el sector de "San Benito" de } \\
\text { la ciudad de Medellín }\end{array}$ & 2015 \\
\hline 6 & LEAL; MONTRONE & Do olhar nos faróis ao convívio com malabaristas: & 2017 \\
\hline 7 & MÔNACO, et al. & Juventude pobre & 2015 \\
\hline 8 & RINCÓN; JIMÉNEZ & $\begin{array}{l}\text { Salud visual y percepción social de malabaristas } \\
\text { de la ciudad de Bogotá }\end{array}$ & 2017 \\
\hline 9 & DOS SANTOS & $\begin{array}{l}\text { O malabarismo nas ruas como alternativa } \\
\text { econômica }\end{array}$ & 2016 \\
\hline \multicolumn{4}{|c|}{ ART } \\
\hline 10 & ARAÚJO & Corpo ativo & 2017 \\
\hline 11 & DE ARAÚJO & Arte Urbana & 2016 \\
\hline 12 & GULARTE & Artista na Rua e Artista de Rua & 2015 \\
\hline 13 & SALGADO & $\begin{array}{l}\text { O Trabalho de Artistas de Rua em Porto } \\
\text { Alegre/RS }\end{array}$ & 2017 \\
\hline 14 & SILVA & Ser, Estar e Fazer & 2017 \\
\hline 15 & VIVERO & Escenarios Callejeros & 2014 \\
\hline 16 & DE ARAÚJO et al. & Arte Invisível & 2016 \\
\hline 17 & SALAMANCA & Arte Bajo la Luz Roja. & 2015 \\
\hline \multicolumn{4}{|c|}{ BACKPACKERS } \\
\hline 18 & HOANG & Mochileros por Sudamérica & 2015 \\
\hline & $\begin{array}{l}\text { DO ESPIRITO SANTO; } \\
\text { NASCIMENTO; ALMEIDA }\end{array}$ & Malabares & 2016 \\
\hline 20 & GROSSI; MIRANDA & Malabarismo no Semáforo & 2015 \\
\hline
\end{tabular}

It was detected that $45 \%$ of the content collected concerning to the activity of juggling at traffic lights is approached from a social and economic perspective, associating the practice of juggling with begging and the territory of the traffic light to drugs and poverty. It is also observed that $40 \%$ of the content describes the activity of juggling as an artistic expression, democratization of art and expression of urban culture. Finally, representing $15 \%$ of the analyzed bibliography, the backpacker's category exposes the condition of the travelers who 
use the practice of juggling at the traffic light to travel the road and guarantee his subsistence and income during the journey (Fig. 2).

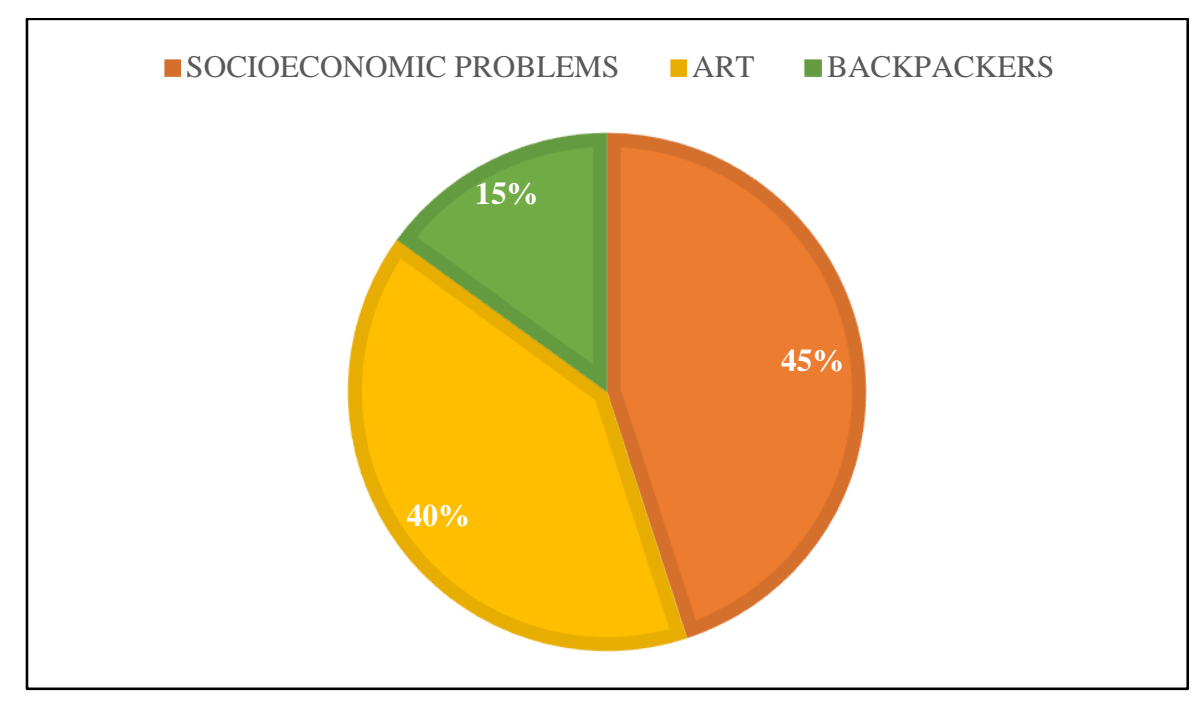

Figure 2. Description of juggling activity, according to revised bibliography.

The socioeconomic category, which presents most of the data collected, presents results relating the practice of juggling at the traffic light with poverty and social inequality. Many of the titles related in that classification frequently use the words: 'excluded' (2) (9), 'beggars' (4) (6) and poor / poverty (1) (7). When the researcher sets his sights for the activity, he sees it as an aspect of the growing inequalities in the cities, which encourage informal income seeking (Tab. 1).

The authors characterize the territory of the street as an environment of fear, drugs and violence (2), considering the workers of that space as marginal and even delinquents. It is important to highlight from this information, that the view of the academy, when viewed in a social way, presents a contemptuous perspective, understanding the characters that perform this practice of the juggling at the traffic lights as beggars and not as artists (1) (2) (3) (4) (5) (6) (Tab. 1).

It is even observed that almost $50 \%$ of the collection of this category (Tab. 2) is aimed at the study of children and young people who perform the circus activity of juggling at the traffic lights (1) (2) (3) (4), representing 4 within the 9 articles. These researches approach this activity as a problem related to the situation of the Latin American population in conditions of inequality, girls and boys who are driven to work from a young age, truncating the normal development of educational, recreational activities and their fundamental rights. 
Table 2. Quantitative of juggling study, based on age group and categories.

\begin{tabular}{|c|c|c|c|}
\hline \multicolumn{2}{|r|}{ AUTHORS } & TITLE & YEAR \\
\hline \multicolumn{4}{|c|}{ SOCIOECONOMIC PROBLEMS } \\
\hline \multicolumn{4}{|c|}{ CHILD WORK $(4 / 9=44 \%)$} \\
\hline 1 & DE ATAÍDE & Meninos Públicos na Via Pública & 2016 \\
\hline 2 & BARBOSA & Territórios dos Excluídos & 2014 \\
\hline 3 & ECKER & Crianças em situação de rua & 2017 \\
\hline 4 & $\begin{array}{l}\text { GÓMEZ; } \\
\text { YEPES }\end{array}$ & $\begin{array}{l}\text { El trabajo infantil en el sector de "San Benito" de la } \\
\text { ciudad de Medellín }\end{array}$ & 2015 \\
\hline \multicolumn{4}{|c|}{ YOUNG AND ADULTS $(5 / 9=56 \%)$} \\
\hline 5 & $\begin{array}{l}\text { BUSCARIOLLI; } \\
\text { CARNEIRO; SANTOS }\end{array}$ & Artistas de Rua & 2016 \\
\hline 6 & LEAL; MONTRONE & Do olhar nos faróis ao convívio com malabaristas: & 2017 \\
\hline 7 & MÓNACO et al. & Juventude pobre & 2015 \\
\hline 8 & RINCÓN; JIMÉNEZ & $\begin{array}{l}\text { Salud visual y percepción social de malabaristas de la } \\
\text { ciudad de Bogotá }\end{array}$ & 2017 \\
\hline 9 & DOS SANTOS & O malabarismo nas ruas como alternativa econômica & 2016 \\
\hline
\end{tabular}

In these articles, the authors see in the same way all the practices executed in the traffic lights, recognizing them as similar activities. That is, the authors define juggling as one of the activities practiced at the traffic light by the socio-economically disadvantaged children and youth community. The category 'art', second largest percentage of the data collected, with $40 \%$, presents a significant value of the bibliography. Such percentage shows even that there are other scientific perspectives that consider the juggling at the traffic light as art and as work. Such articles study street art in its entirety, thus giving them an artistic character promoted by subjects that occupy public spaces such as the street.

In this way, the articles of that category assume the practice of juggling at the traffic light as a 'job', presenting the intrinsic characteristics to that activity. The authors expose, from the perspective of the artists, the difficulties, the pleasures, the advantages and disadvantages realizing this work. Approaching this way, a vision that goes beyond the perspective of this work as expression of urban art and a way to democratize art.

The category 'backpackers' refers to the practice adopted by itinerant artists who dedicate their lives to travel different countries in a sustainable way for long periods or permanently, trading and / or selling their work to meet the basic needs of food, clothing and lodging (GULARTE, 2015). They are a group of individuals of different nationalities who migrated from their home to make a trip (in most cases) without time and / or destination. This kind of people are called "backpackers", described as people who travel the world (HOANG, 2015) traveling with very little money, carrying only a travel backpack, some 
clothes, basic cleaning materials, their work tools, maybe some material to make crafts and a musical instrument.

According to the content of $15 \%$ of the bibliography reviewed, the jugglers who act in the traffic lights belong to this social group and from their own perspective, considering themselves heirs of a capitalist, imperialist and consumerist society; from which they want to detach themselves in search of individuality, authenticity, independence and evading materialism; interpreting his trip as an expression of the counterculture today (SILVA, 2017). They also seek to have a special connection with art, be it any kind of manifestation through which they can express their thoughts and feelings, in addition to appropriating it as a means of survival, taking advantage of the fact those traffic lights are a common element in most cities.

It is also worth noting that there was difficulty in classifying two articles between the socioeconomic and art categories. The first was the article "Street artists - workers or beggars" by Buscariolli, Carneiro and Santos (2016). This study presents an analysis about the artist, the public, the art, the interaction and the environment; showing the perspective of the author in relation to the presentations and the reactions of the public. Even making a greater number of observations among the street artists in the musical area, the authors also add to the compiled of data the presentations of jugglers and comment that "there was doubt about the consideration of them as artists" since they presented a "minimum level" of preparation" (BUSCARIOLLI; CARNEIRO; SANTOS, 2016, p. 884). In this case, it is possible that there is a lack of knowledge, which the author has in relation to the preparation and training necessary to perform such activity (subject to be discussed in the analysis of the results). In their discussions, writers consider street performers sometimes beggars and on other occasions artists. The article considered in the socioeconomic classification for presenting social and economic discussion in the textual construction and especially for the treatment that the authors present with relationship to the jugglers, that is, in the doubt of considering them artists.

The uncertainty in the second article, entitled "Being and doing: Notes about the street circus in the Amazon" by Silva (2017), comes from the characteristic of the text presented. The study shows the experience of the author as a juggler and brings, therefore, social and economic / financial aspects of that experience. However, the focus of the study presents the characterization of the activity studied as an art, becoming different from articles classified as socioeconomic. It was decided then, that the article belongs to the group 'art' to relate mainly the activity in study, to the aspect of art as work. 
To conclude, it is also valid to point out that it is possible to perceive that the socioeconomic classification presents a more external view of the 'street economic activities', making ethnographic and observation researches, in which the authors did not come into contact with the subjects who carried out this activity. Different from the category 'art' in which an internal vision of the activity is expressed, giving voice to the street jugglers, approaching their perspective in relation to the work they do, presenting the analysis from an intrinsic approach to activity.

\section{DISCUSSION}

\section{Socioeconomic Perspective of Street Art}

The tendency of the authors to approach the topic of traffic light artists as a socio-economic problem shows that there is a generalized preconception within the society, which is not familiar with alternative ways of work (SALGADO, 2017) different from those established by capitalism's patterns. There is a perception that the practice of juggling at the traffic light is executed only to 'ask for money', or is associated with a stereotype of people unwilling to work or want to use that money for drug use.

Authors such as Barbosa (2014), for example, present the space of the street as a territory and that of the traffic light as a 'nano-territory' relating it to drugs, violence and fear. This study discusses the activity of juggling at the traffic light made by excluded children and youth, addressing the risks and consequences that this child-youth community can suffer. Among the data collected, there were several others that analyzed the perspective of child labor (DE ATAÍDE, 2016; ECKER, 2017; GÓMEZ; LÓPEZ; YEPES, 2015).

These studies present the activity of juggling (within other practices - asking for money, cleaning glass, sell candies, etc.) as a way of subsistence (BARBOSA, 2014; ECKER, 2017), becoming a form of child exploitation that will affect their development as an individual in society. The studies also address the preconception, exclusion and stigmatization of these children (BARBOSA, 2014; DE ATAÍDE, 2016; ECKER, 2017), the look of repudiation and disdain of passersby can alter the perception of the child about his feeling of belonging to the world (ECKER, 2017). Still commented by Ecker (2017) such repudiation occurs because "that child who would be seen as innocent if he were in another social context, at the traffic light is interpreted almost as a delinquent adult" (ECKER, 2017, p. 147).

In this way, is highlighted that various groups such as people living in the street or juggling traffic lights are marginalized from society, lacking the same opportunities, rights, access and material, immaterial or symbolic conditions that others have. (LEAL; 
MONTRONE, 2017). This statement generalizes the profile of jugglers who work at traffic lights, ignoring the sociocultural diversity of these individuals, since each one arrives at this situation in different social, educational, cultural, religious and ideological conditions, but as a reflection of social inequalities, economic, cultural and relationship with the authorities (SILVA, 2017).

According to the interviews made by Vivero (2004), jugglers declares that the fact of going to the traffic light does not mean a condition of begging, it is simply the most practical way to obtain some income as a complement to their main activity. Also demonstrated by Rincón and Jiménez (2017), when analyzing a group of jugglers who declared to be studying university careers with the objective of obtaining fixed income and ending their economic dependence on juggling. In addition to this, they feel themselves agents of the art expecting that society to see them in the same way, manifesting categorical in holding that they are not beggars, unemployed, gypsies or hippies (DO ESPÍRITO SANTO; NASCIMENTO; ALMEIDA, 2016).

It should be noted that these artists go through various difficulties to be present in these spaces, in the work of Buscariolli, Carneiro and Santos (2016) conducting a field research on street artists in the city of São Paulo. It was noted that all artists were demonstrating "physiological difficulties", deprivation of public baths, the climate, direct exposure to the sun (therefore to ultraviolet light) during prolonged periods, little water ingestion and "lack of safety precautions during presentations". (RINCÓN; JIMÉNEZ, 2017).

Contrasting these statements that link juggling at the traffic light with poverty, a research published in 2016 in the Brazilian city of Cuiabá (DOS SANTOS, 2016), with questions made to eight jugglers, gave as a result that in a good day of work they obtained between R \$ 30,00 and R \$ 100,00 (between US\$ 8,11 and US\$ 27,00) ${ }^{1}$ per day. Although the term "work" is widely recognized as the action that human beings perform in order to satisfy their primary needs, exists a certain social resistance to recognize street art as such.

\section{Street Art}

In countries with high levels of unemployment, it is much more frequent to observe people using informal ways to make money, many of them occupying public spaces in front of bars and restaurants, on platforms, squares, pedestrian streets and traffic lights (DOS SANTOS, 2016). The types of artistic manifestations are varied: human statues, comedians, storytellers,

\footnotetext{
${ }^{1}$ Exchange rate on Tuesday, June 12, 2018.
} 
theatrical pieces, balance numbers, music, magic acts, juggling, swing, staff contact, acrobatics, hoops, diabolo, graffiti, dances, etc. (BUSCARIOLLI; CARNEIRO; SANTOS, 2016; SALGADO, 2017; VIVERO, 2014). Street art exceeds the limits of galleries, circuses, theaters; that is to say, closed places where the artistic manifestations are exhibited in a more restricted way (BUSCARIOLLI; CARNEIRO; SANTOS, 2016), facilitating access to the whole community, by making their presentations in public places; as long as the supervising authorities of the public space allow its realization.

In the research conducted by Salgado (2017) in the city of Porto Alegre - Brazil, with street artists asked about their considerations on street art, three aspects were highlighted: pleasure and sustenance, freedom of creation and democratic art; all these factors expressed as a representation of resistance against the working conditions of the working class. According to her affirmations, making art in the street allows to work in something that enjoys and that allows freedom of time and choice. The street artist must build his own stage and seek interaction with his audience, which is not always exactly 'there' to watch his show and therefore, have no obligation to correspond to the presentation in any way.

\section{Juggle}

Informally speaking, the expression 'juggle' is used to refer to the situation of carry out multiple activities simultaneously; however, in more specific terms, juggling is a circus art that consists of achieving physical and visual feats through the manipulation of objects (MÔNACO et al., 2015), becoming an artistic, physical and social practice.

According to the Etymological Critical Dictionary Castilian and Hispanic (COROMINAS; PASCUAL, 1989) the word 'Malabar' in the Romance languages had its origin in a village with this name, located on the west coast of India where its aboriginal settlers had a great skill with launching, receiving and manipulating objects; this term was adopted by the Portuguese colonizers and later by the Spaniards. There are also Egyptian hieroglyphs found in the sarcophagus of Pharaoh Beni-Hassan from about 4000 years ago where human figures were represented throwing several objects simultaneously (DO ESPÍRITO SANTO; NASCIMENTO; ALMEIDA, 2016).

The tools used to juggle called toys, allows an infinite possibility of movements and 'tricks', creating a plurality of styles and movements in each juggler (SILVA, 2017). The difficulty of juggling is in the relation of the toy with the body; in this order of ideas, it is correct to say that training makes the circus artist. To more constancy, the bond and the harmony of the objects manipulated by the artist is better. This artistic representation 
reinforces the popular knowledge that indicates how important the practice is to achieve perfection in any activity that the human being wishes to execute.

Juggling at the traffic light is a recent phenomenon compared to the other economicartistic alternatives adopted by some young people excluded from the formal labor market. At the same time contributing a significant cultural component to the current situation of public space (DOS SANTOS, 2016); starting to emerge as a component of street art, the diversity of cultures within society and the cities of the 21 st century.

The presentation of numbers at the traffic lights is a practice in which the artist has approximately thirty seconds to execute his demonstration in a daily space for the population, breaking with that routine absorption of the inhabitants in the cities, taking advantage of a forced moment of waiting in the lives of people (GULARTE, 2015). Juggler emerges as a figure that occupies a concurred space 'breaking the bubble' of the common citizen (MÔNACO et al., 2015) imprisoned in their daily lives and creating a "leisure bubble" accepted by some motorists who allow themselves to enter and participate of a public artistic presentation, rescuing streets and avenues as free spaces. Exploiting it to generate situations that come to be part of the current social aspects of today and giving access to an artistic presentation, including people who do not have time or money to go to the theater or to the circuses.

For Salamanca (2015), the practice of juggling at traffic light is an art that produces amazement and admiration, seeing how these subjects use the space of greater interaction existing in human civilization as a battlefield, creator of stimulation and as a showcase for his show. Authors affirm that in order to juggle at traffic lights, the state of mind and technique obtained through training are important, this with the aim of transmitting serenity, happiness, security and attracting public attention (SILVA, 2017). However, according to Buscariolli, Carneiro and Santos (2016) the preparation and interaction of the street artist with the public do not interfere in the economic gain. This sentence evidence that there is a contradiction between the theories of these authors, originated perhaps by the fact of Silva having done his research in the Amazonian region, while Buscariolli did it in São Paulo: two geographical points with different social and economic characteristics.

The intention of the artist is to awaken sensations in his audience. In this same way, the juggler who uses the traffic lights as stage, seeks to give a moment of joy and win smiles from the motorists who usually feel afraid only because of that person bring closer: they close the car window, hide their valuables; and also of some pedestrian who prefer to cross to the other side of the street (BUSCARIOLLI; CARNEIRO; SANTOS, 2016; BARBOSA, 2014; 
DE ATAIIDE, 2016; ECKER, 2017; LEAL; MONTRONE, 2017). Faced with these circumstances, the jugglers say that the street is a school, a place of learning par excellence where there are constantly unexpected and often inevitable interactions, unusual situations that form the character (ECKER, 2017; SILVA, 2017).

Perform circus acts is not limited to the act of making that presentation reduced to less than a minute, since there are many previous stages that form a process of continuous improvement with training and the manufacture of the elements used in the show (SILVA, 2017). Such stages of preparation are apparently unknown to society and ignored by the academic community and in this sense, the article by Buscariolli, Carneiro and Santos (2016) comments in a study in which researchers analyze the quality of the artist's street. Within the topics studied includes observations in relation to the artist (appearance) and in relation to the presentation (performance).

However, when describing the presentation of an acrobat in a square, whose presentation consisted of jumping through a circle of knives, the researchers instead of observing the performance, as presented in their methodology, tells only about the strategy used by the artist (delay in the execution) of the performance. The authors when writing the observations relate as "apparently simple presentation". That is, researchers consider that jumping through a circle of knives is a simple presentation. It is therefore observed that when the academic community directs its attention to the presentation, it does not take into consideration the necessary stages for the artist to be ready for the performance, it should be noted that the authors do not know the level of training for the execution of such activity.

Learn and develop new tricks in the circus arts allows to explore more widely the own conception of the body and develop a plurality that goes beyond the simple artistic demonstration. For street artists, it is sometimes important to move from the limits of the traffic light, to do circus activities through workshops open to the public, meetings of jugglers, trainings and some lucky special works of entertainment at events (SILVA, 2017).

With these activities outside the circus tents, individuals occasionally concentrated in groups seek to propagate circus knowledge; sharing the idea of self-management and with the desire to show the public that their work is serious, in addition to being an activity where it is possible to have fun and be distracted. They are generally willing to share their knowledge and teach tricks to anyone who expresses interest, interrupting without problem the activity that is running at the time, considering sharing the art an important value of the street circus for that same notion of the democratization of art (SILVA, 2017). 
From the perspective of the jugglers, their identity is constructed and can be reinforced through the following factors (DO ESPÍRITO SANTO; NASCIMENTO; ALMEIDA, 2016). First, exists a declaration of belonging when they call themselves artists; second, when there is an element of justification, referring to surviving with the money raised in their presentations and third, presenting a discursive strategy by disconnecting from routine and living their life as an adventure.

The informality of juggling is not only an option of life, it is a lifestyle for those who have the art of juggling as a profession; it is an alternative means of associating talent, art and sufficient material needs not only to economic satisfaction and professional fulfillment, but also a way of resisting the exclusion of capital (DOS SANTOS, 2016).

\section{Backpackers}

In this section of the article, the phenomenon of individuals who dedicate their lives to travel through different countries for long periods or permanently working with juggling at the traffic light is discussed (GULARTE, 2015). Enthusiasts of the cultures of the planet, of nature, seekers of happiness and citizens of the world who receive each day in an improvised manner, detached from any type of predetermined programming or routines.

The reasons that a human being travels are varied: the possibility of escaping from the everyday environment dominated by the lack of opportunities in his place of residence or the monotony of a little-estimated work, the possibility of emigrating with the possibility of choosing the city where you will live, knowing it in a prior and meticulous way (HOANG, 2015). Another important aspect is the search for happiness, feeling that the normal life linked to our production system does not provide sufficient guarantees, generating a waste of your lifetime by living a constantly repetitive and boring routine. Given these circumstances, these people decide to travel in order to connect with their inner self, without luxuries, with basic food, resting in a place where there is a roof.

Traveling in this way, allows the backpacker to know the cities by their own means, cities' roots, gastronomy, population, customs; causing a more direct contact with the community. That is to say, in a different way from that traditional tourism carried out by people arriving at the airport going directly to the hotel, driven by a tourist guide who presents the tourist places of interest in the city. Backpackers have the characteristic of traveling cheaply with low budget and disinterested by the systematic consumption of products and services (different from those that supply basic human needs), these characteristics make them become an unattractive social group for the authorities of tourism 
that do not frequent to execute investigations with the objective of studying this social group (HOANG, 2015).

There is no exact information that indicates the birth of the act of traveling as a backpacker, especially because there is a lack of sufficient theoretical fundamentals that explore the work of itinerant travelers. Everything indicates that it is a recent activity, probably since the 1990s and in constant growth (HOANG, 2015).

It should be noted that the circus always had a nomadic character inherent in its history. According to Araújo (2017), the arrival of the traditional circus to Latin America in the 20th century already had a nomadic and familiar configuration. Still according to the author, "there is a strong movement of presentations in the traffic lights of cities, common practice today. Artists continue to be nomads" (ARAÚJO, 2017, p. 29). Most of them stay in the cities for some days or weeks collecting money to continue their trip, while they know the places of interest of the city visited, on the other hand, Dos Santos (2016) states that some individuals remain in the same city during months and even years, some of them within a family with children.

In this way, it is perceived that the activity of the circus artists traveling making their presentations in the way traveled was always intrinsic in the history of the circus activity as a whole. That is, the association of circus activity with the group of backpackers, despite appearing as the least punctuated topic of the bibliographic collection, presented in an accurate manner.

Do Espírito Santo, Nascimento and Almeida (2016) revealed that $75 \%$ of these individuals are between 20 and 28 years old, and had a travel time between 1 and 4 years. They also declared had suffered prejudice from agents of the Brazilian Federal Police, with whom they have an obligation to make contact in order to regularize their passage through the international frontier. They also indicated that it is possible to change abruptly the journey of their trip; this indicated from a precedent of migratory problems within this social group, such as irregular entry, the expiration of their temporary visitation or problems due to the exercise of an activity prohibited in some cities (DO ESPÍRITO SANTO; NASCIMENTO; ALMEIDA, 2016).

Agents of the police or migratory entities sometimes apprehend the toys or arrest jugglers in the exercise of their practice to take them to temporary prisons, in situations generally called "cleaning of the city". Sometimes they are deported to the international border closest to their country or directly to it, at other times, after keeping them imprisoned 
for a few days they are released; this situation is peculiar in Ecuador, which draws attention for its substantial amount of deportations.

The authorities responsible for these arrests argue that according to the entry document granted at the international border, this person has the character of a temporary visit in the country as a tourist, being prohibited therefore, the execution of any activity that may generate any profit. Generally, the jugglers arrive to the countries by land obtaining their "migratory regularizing document" directly in the service window in the migration office of the international border; they do not have access to the work visa that allows executing their livelihood activity in a way regularized. For the traffic light jugglers, these situations are illogical because "borders do not exist, they are a political invention of humanity" (DO ESPÍRITO SANTO; NASCIMENTO; ALMEIDA, 2016).

\section{ACKNOWLEDGEMENTS}

Thanks to all the people who inspire us for to do this research. To the artists, street light jugglers, who transmit his happiness and art to the society; also every authors used in the bibliography research, who with courage and determination approach this hard and polemic topic, little studied in the academic community. Thanks to everybody that contribute for the construction of present work.

\section{REFERENCES}

ARAÚJO, J.A.B. Corpo ativo: vivências da corporeidade circense. 61 f. Trabalho de conclusão de curso (Licenciatura em Pedagogia)-Universidade de Brasília, Brasília, 2017.

BARBOSA, R.S. Territórios dos Excluídos: as territorializações de crianças e adolescentes em situação de risco no espaço urbano de Campina Grande - PB. 150 f. Dissertação (Mestrado em Geografia)-Universidade Federal de Pernambuco, Recife, 2014.

BARDIN, L. Análise de Conteúdo. Lisboa: Edições 70, 1977.

BUSCARIOLLI, B.; CARNEIRO, A.T.; SANTOS, E. Artistas de rua: trabalhadores ou pedintes? Cadernos Metrópole, São Paulo, v. 18, n. 37, p. 879-898, 2016.

COROMINAS, J.; PASCUAL, J.A. Diccionario crítico etimológico castellano e hispánico. Madrid: Gredos, 1989. 
DE ARAÚJO, A.T.; NEGRINI, G.B.; VALE, L.R.; SUAIT, L.O.; PEREZ, P.V.; VIANA, P.M.F. Arte Invisível. Intercom - Sociedade Brasileira de Estudos Interdisciplinares da Comunicação - XXIII Prêmio Expocom, Poços de Caldas, 2016.

DE ARAÚJO, W.O.C. Arte Urbana: A cultura marginal em Macapá. Ciência e Sociedade, Macapá, v. 1, n. 1, 2016.

DE ATAIIDE, M.A. Meninos Públicos na Via Pública: O Malabarismo como Espetáculo ou a Reprodução da Pobreza. Emancipação, Ponta Grossa, v.16, n.1, p. 145-161, 2016.

DO ESPÍRITO SANTO, A.L.; NASCIMENTO, R.F.; DE ALMEIDA, R.B.F. Malabares: Um Olhar sobre a Fronteira Brasil/Bolívia. Perspectiva Geográfica, Marechal Cândido Rondon, Ed. Esp., v. 11, n. 15, p. 13-22, 2016.

DOS SANTOS, J.B. O malabarismo nas ruas como alternativa econômica aos jovens excluídos do mercado formal de trabalho. Profiscientia, Cuiabá, n.10, p. 51-63, 2016.

ECKER, D.D.I. Crianças em situação de rua: malabares da exclusão. Ciências Psicológicas, Porto Alegre, v. 11, n. 2, p. 139-148, 2017.

GÓMEZ, D.I.H.; LÓPEZ, S.P.P.; YEPES, L.M.C. El trabajo infantil en el sector de "San Benito" de la ciudad de Medellín: diagnóstico y propuesta de intervención. 26 f. Tesis de Grado Corporación Universitaria Minuto de Dios, Facultad de Ciencias Humanas y Sociales, Trabajo Social, Medellín, 2015.

GROSSI, A.L.; DE MIRANDA, A.C.M. Malabarismo no Semáforo: Um diagnóstico do Artista de Rua na cidade de Maringá-PR. 24 Encontro Anual de Iniciação Científica - 4º Encontro Anual de Iniciação Científica Junior, Maringá, 2015.

GUlARTE, J.A.F. Artista na Rua e Artista de Rua: Enfrentamento e resistência. 85 f. Dissertação (Mestrado em Artes)-Universidade Federal de Santa Maria, Santa Maria, 2015. 
HOANG, R.L.Z. Mochileros por Sudamérica. Aportes de la comunicación, Santa Cruz de la Sierra/Bolivia, v. 19, p. 31-39, 2015.

LEAL, P.H.; MONTRONE, A.V.G. Do olhar nos faróis ao convívio com malabaristas: a prática social do pedir nos semáforos. Educação e Cultura Contemporânea, Campinas, v. 15, n. 38, p. 265-294, 2017.

MÔNACO, C.M.; CHAGAS, V.B.; NASCIMENTO, R.D.; BIGELI, A.R.F.; CRUZ, M.G.A.; SILVA, S.I.M.; DA SILVA, M.L.; CRUZ, S.G.F.P. Juventude pobre: arte, psicologia e política. $8^{0}$ Congresso de extensão universitária, Universidade Estadual Paulista, p. 1-6, 2015.

RINCÓN, K.N.S.; JIMÉNEZ, I.A.B. Salud visual y percepción social de malabaristas de la ciudad de Bogotá, Colombia. Universidad y Salud, Bogotá, v. 19, n. 3, p. 340-351, 2017.

SALAMANCA, V.D.L. Arte bajo la luz roja. 40 f. Trabajo de grado Universidad Pedagógica Nacional, Bogotá, 2015.

SAlgADO, C.P. O Trabalho de Artistas de Rua em Porto Alegre/RS. 93 f. Dissertação (Mestrado em Serviço Social)-Pontifícia Universidade Católica do Rio Grande do Sul, Porto Alegre, 2017.

SILVA, J.O. Ser, estar e fazer: Notas sobre circo de rua na Amazônia. PROA - Revista de Antropologia e Arte, Campinas, v. 2, n. 7, p. 25-46, 2017.

VIVERO, S.M. Escenarios Callejeros: Un Espacio de Formación, Exhibición y Vivienda de Artistas Callejeros. 70 f. Trabajo Final de Carrera-Facultad de Arquitectura, Diseño y Artes Pontificia Universidad Católica del Ecuador, Quito, 2014. 